\title{
O'CONNORITE BEDLAM: FEARGUS AND HIS GRAND-NEPHEW, ARTHUR
}

\author{
by
}

\section{LAURENCE M. GEARY*}

\begin{abstract}
The vessels of the head suffer in common with the rest. ${ }^{1}$
\end{abstract}
It was a fine morning, Queen Victoria observed. After breakfast, she became aware of the crowds congregating outside Buckingham Palace. For this day of thanksgiving, 27 February 1872, the Queen's habitual widow's weeds were trimmed with miniver and her bonnet adorned with white flowers and a white feather. At 12.05 p.m., she took her place, together with the Prince and Princess of Wales and their children, in an open state landau, drawn by six horses and ridden by three postilions. As on all state occasions, the Queen was given a sovereign's escort. The procession was led by the carriages of the Speaker, the Lord Chancellor, and the Commander-in-Chief. Their destination was St Paul's Cathedral, where a thanksgiving service was to be celebrated for the recovery of the Prince of Wales from a near-fatal bout of typhoid fever. His recuperation, however, was far from complete. "Bertie", his mother noted, "was very lame and did not look at all well".

Nonetheless, the nation's mood was festive and for millions of Londoners it was a day of carnival. In contrast to the all-pervading loyalty without, the Queen found the interior of St Paul's "dull, cold, dreary and dingy", the service "cold and too long". It was with some relief that the royal party embarked on the homeward journey. Once ensconced within the palace precincts, the Queen reflected on the day's events and concluded that it was an occasion to be treasured. ${ }^{3}$

Nor would it be forgotten by the armed youth who lurked outside. His plan of confronting the monarch in the aisle of St Paul's and demanding the release of the imprisoned Fenians in return for her safety was foiled on the eve of the ceremony, when he was discovered by the verger and escorted from the cathedral. His quarry eluded him on the following morning also, but on the afternoon of 29 February, fortune beckoned.

As the Queen's open landau approached the garden entrance to Buckingham Palace on her return from her daily airing in Hyde Park and Regent's Park, and with

\footnotetext{
${ }^{*}$ Laurence M. Geary, MA, Ph.D., Department of Economic and Social History, University of Edinburgh, William Robertson Building, 50 George Square, Edinburgh EH8 9JY.

${ }^{1}$ William Willis Moseley, Eleven chapters on nervous and mental complaints, London, Simpkin, Marshall \& Co., 1838, quoted in Vieda Skultans (ed.), Madness and morals. Ideas on insanity in the nineteenth century, London and Boston, Routledge and Kegan Paul, 1975, p. 47.

${ }_{2}^{2}$ George Earle Buckle, The letters of Queen Victoria, 3 vols., London, John Murray, 1926-8, vol. 2, p. 194.

${ }^{3}$ Ibid.
} 
the expectant milling about the gates, her athletic pursuer scaled the 10-foot-high railing and, unobserved, made his way across the courtyard. Unhindered and unchallenged, he appeared at the window of the Queen's carriage and pointed the pistol at her head. Instinctively, she threw herself upon her travelling companions; her attendant, John Brown, and her sons, Arthur and Leopold, hurled themselves at her assailant and knocked the weapon from his hand. "All were white as sheets", the Queen later recorded, "Jane C[hurchill] almost crying, and Leopold looked as if he were going to faint". 4 They were not to know that the inexperienced gunman had broken the lock of his pistol, thus rendering it harmless.

Public reaction was unequivocal. The Times condemned the outrage as a "miserable and dastardly attack ... the isolated freak of a disordered brain". The Queen's assailant was dismissed as "a half-witted boy" whose mind "was one of those which do not observe any laws of reasoning, but move by the unregulated impulses of insanity". A motive was posited: "If his reported parentage is found to be true, there will be no difficulty in understanding that he may have been predisposed by inheritance to lose his head in the pursuit of frenzied designs". 5

The youth turned out to be Arthur O'Connor, a grand-nephew of the Chartist leader, Feargus O'Connor, quondam MP for County Cork and subsequently for Nottingham, whose idiosyncratic behaviour twenty years earlier had made him the bete noire of the House of Commons. He was committed to a private lunatic asylum in June 1852, after striking a fellow Member in the House.

The O'Connors were unconventional and idiosyncratic, possessing, as a family, more skeletons than closets. Feargus's grandfather, Roger Conner, was an eccentric, with a penchant for collecting horse droppings. ${ }^{6}$ His sons, Roger and Arthur, Feargus's father and uncle respectively, rejected their patronymic in favour of the surname O'Connor, after the ancient line of Irish high kings. Subsequently, these descendants of London merchants saw neither dichotomy nor irony in their self-hypnotic belief in their own royal lineage and their fervent espousal of Irish republicanism. In the 1790 s, their commitment to United Irish ideals was matched only by the fervour with which their other brothers rejected them. The eldest, Robert, remained staunchly loyal and his zealous attempts to secure the execution of his treasonable siblings shocked even the Irish authorities. Arthur played a significant role in the United Irish movement, suffered several years' imprisonment and narrowly escaped the gallows. He spent half a century in exile, became a Napoleonic general, and married Eliza, only child of Condorcet and niece of Marshal Grouchy, who bore him three sons to add to his illegitimate one. The most recent historian of the United Irishmen has depicted O'Connor as irresponsible, ambitious, and egotistical, and concluded that his megalomania wreaked havoc within the movement. ${ }^{7}$ Amourpropre was an aberration he shared with his nephew, upon whom Daniel O'Connell

\footnotetext{
${ }^{4}$ Ibid., pp. 197-8.

5 The Times, 1 March 1872.

${ }^{6}$ W. J. O'Neill Daunt, $A$ life spent for Ireland, London, T. Fisher Unwin, 1896, repr. with an introduction by David Thornley, Shannon, Irish University Press, 1972, p. 290.

${ }^{7}$ Marianne Elliott, Partners in revolution: the United Irishmen and France, New Haven and London, Yale University Press, pp. 99-100. See also Frank MacDermot, 'Arthur O’Connor', in Irish hist. Stud., March 1966, 57(15): 48-69.
} 


\section{O'Connorite Bedlam}

bestowed the sobriquet, "Poor Balderdash". The Liberator described Feargus's newspaper, the Northern Star, as "a literary curiosity. The first page is filled with praise of Feargus; second page, praise of Feargus; third page, ditto; fourth page, ditto; and so on all through till we come to the printer's name". 8 While Arthur prospered in exile, his brother, Roger, in a too-literal interpretation of French revolutionary ideals, embezzled his Irish estate. In addition, Feargus's father fired his own property for the insurance money, held up the Galway mail coach in 1817 and subsequently robbed a land agent of $£ 750$. He was twice married, ending his days in concubinage in a cottage near Ballincollig, County Cork, with the daughter of a fishmonger named Sullivan, whom he grandly rechristened Finina. ${ }^{9}$ Few would cavil with the assessment by Roger's cousin and neighbour that he was "eccentric and imaginative". 10 However, it is altogether mischievous to assert, as Feargus's biographers have done, that "Roger O'Connor was clearly unbalanced, probably by the end of his life positively insane". 11 Such vacuous speculation is poor historiography.

Several of the father's traits were visited on the children, at least three of Roger's sons being of a highly adventurous nature. The eldest, Roderic, betook himself and his two illegitimate sons to Van Diemen's Land, arriving there on board his own ship, Ardent, in May 1824. He filled various roles in the public service and by the time of his death in 1860 had become one of the colony's largest landowners. Litigious, quarrelsome, and egotistical, his irascibility increased with age. He was described by Lady Franklin, wife of the lieutenant-governor, as "a man of blasted reputation, of exceedingly immoral conduct and of viperous tongue and pen". 12 Roderic was to have been accompanied to the Australian colonies by his half-brother, Francis Burdett O'Connor, but the latter embarked instead for South America, where he became successively a general in the Bolivian army, minister of war, and chief of the general staff. ${ }^{13}$ But the cynosure of Roger O'Connor's children was his second youngest son, Feargus Edward. He was in the public eye as an elected representative for Irish and English divisions and as a Chartist leader-simultaneously its most popular and most reviled figure-for a score of years before his increasingly eccentric behaviour toppled over into certifiable insanity in June 1852.

The onset of the malady that was to end fatally in 1855 can be traced to the difficulties associated with the National Land Company, O'Connor's Tolstoyan scheme to make "a paradise of England". ${ }^{14}$ In the mid-1840s, British workingmen subscribed more than $£ 100,000$ for the purchase of land which was to be allotted to members chosen by ballot. The ideal was frugal comfort and independence in return

${ }^{8}$ Daunt, op. cit., note 6 above, p. 25.

${ }^{9}$ Ibid., pp. 249-52.

${ }^{10}$ Idem, Eighty-five years of Irish history, 1800-1885, London, Ward and Downey, 1888, p. 134.

${ }^{11}$ Donald Read and Eric Glasgow, Feargus $O^{\prime}$ Connor: Irishman and Chartist, London, Edward Arnold, 1961, p. 13.

${ }^{12}$ P. D. Eldershaw, 'Roderic O'Connor' in Australian dictionary of biography, 11 vols., Melbourne University Press, 1966-88, vol. 2, pp. 296-7; idem, introduction to Anne McKay (ed.), Journal of the Land Commissioners for Van Diemen's Land, 1826-28, Hobart, University of Tasmania in conjunction with the Tasmanian Historical Research Association, 1962.

${ }_{13}$ Burke's Irish family records, London, Burke's Peerage, 1976, pp. 265-7.

${ }^{14}$ Northern Star, 8 May 1847, quoted in Read and Glasgow, op. cit., note 11 above, p. 112. 


\section{Laurence M. Geary}

for modest endeavour. But the reality was different. Urban artisans lacked agricultural expertise and most of the 250 assignees found the transition difficult. Few managed to prosper sufficiently to pay rent. Such difficulties would have been overcome in time, but the legal obstacles proved to be insuperable. For a variety of reasons, the company was never fully registered. Consequently, O'Connor was compelled to purchase land in his own name, thereby fuelling suspicions of peculation and personal aggrandisement.

In March 1848, he moved to introduce a bill in the Commons to bring the National Land Company under the Friendly Societies Act. The bill did not get a second reading. Instead, the Commons appointed a Select Committee to inquire into the company's affairs. The committee reported in the summer of 1848 that the scheme was inconsistent with the principles on which friendly societies were founded; the land company, as constituted, was illegal; and its financial affairs were in complete disarray: the committee recommended that it be wound up. O'Connor was cleared of any impropriety; the company's difficulties were due to gross mismanagement, not misconduct on his part. In fact, the committee reported that O'Connor had sunk more than $£ 3,000$ of his own money in the project. ${ }^{15}$

In March 1853, Dr Thomas Harrington Tuke, ${ }^{16}$ the alienist physician under whose psychiatric care O'Connor had been for the previous nine months, informed Ernest Jones, leading Chartist and editor of the People's Paper, that it was the collapse of the land company or, more specifically, the negative reaction of professed friends and supporters that precipitated O'Connor's mental crisis. ${ }^{17}$ Clearly influenced by his interview with Tuke, Jones offered a similar aetiology when, a month later, he testified before a Commission de lunatico inquirendo, to investigate the state of O'Connor's mind. Jones depicted O'Connor as physically and intellectually powerful, abstemious in private, vigorous, decisive, and indefatigable in public. His preoccupation with the land scheme was total. "He would talk-he seemed to think of nothing else-and used to say, when adverting to the greatness of the subscriptions, 'I shall establish such a movement as the world has never seen-it will be the salvation of the English People'... His whole soul seemed bound up in the undertaking". With the appointment of the Commons Select Committee, a noticeable change came over O'Connor; he suffered memory lapses, repeated himself constantly, and expressed contradictory views and advice. "It was evident", Jones concluded melodramatically, "the great mind was beginning to totter on its throne, and balancing itself to and fro before plunging in its fall". ${ }^{18}$

Jones spent the next two years in prison and on his release, in mid-1850, noticed a marked deterioration in O'Connor's condition, specifically, loss of memory, delusion, lack of self-control. "He would break into a fit of laughter without any apparent cause and burst into tears, similarly without any discernible reason". 19 Dougal

\footnotetext{
${ }^{15}$ Sixth report from the select committee of the National Land Company; together with the proceedings of the committee. H. C. 1847-8 (577) xix. 333.

16 1826-88; MD St Andrews, 1849; FRCP Edinb., 1858; FRCP Lond., 1868; son of Edward Francis Tuke, MD of Bristol. See obituary notices in Lancet, 1888, i: 1208, 1274; Br. Med. J., 1888, i: 1364.

17 People's Paper, 12 March 1853.

18 The Times, 13 April 1853; People's Paper, 16 April 1853.

19 Ibid.
} 


\section{O'Connorite Bedlam}

McGowan, a printer and long-time acquaintance, also testified to O'Connor's memory lapses, lack of concentration, and changed behaviour patterns about this time. ${ }^{20}$ By 1851, O'Connor's idiosyncracies had become public knowledge. At the demonstrations and banquets to mark the arrival in England of Lajos Kossuth, the Hungarian patriot, O'Connor's effusions caused universal embarrassment. ${ }^{21}$ Jacob Bell $^{22}$ referred to O'Connor's increasingly eccentric behaviour in the House of Commons: "He would go round and shake hands with the whole house, beginning at the treasury bench and ending at the other end, saying to everyone, 'You're a jolly good fellow' ". ${ }^{23}$ On 2 February 1852, an inquiry was opened before a Master in Chancery into the management and finances of the National Land Company, with a view to winding up its affairs. O'Connor, who was cross-examined for nearly five hours, claimed that he had received nothing but abuse in return for his efforts to ameliorate the lot of the English working man. But, he continued,

If Prince Albert had built these cottages and located these lands, there would have been offices to promote them in every street in London for the benefit of these poor people, under the patronage of the philanthropic prince; but now if my Lord or Lady Nincompoop happens to be driving through these estates and the daughter of the carriage happens to say, "Lor', mama, look at those beautiful cottages!", the anxious parent pulls down the blind, exclaiming, "My dear, it is that ruffian Feargus O'Connor built them". [Loud laughter].

O'Connor's evidence, according to one newspaper report, was given in "a semi-serious but insulting manner". He proffered the Master a pinch of snuff, described the opposing counsel as a ruffian and offered to order him a mutton chop to assuage his hunger. ${ }^{24} \mathrm{His}$ behaviour during the remainder of the week became even more markedly extravagant. Dougal McGowan, who attended the proceedings, testified that O'Connor's conduct "was that of a madman". ${ }^{25}$ There was a widespread, but erroneous, belief that he was shamming in order to shun inquiries into the affairs of the land company. ${ }^{26}$ The hearing was adjourned on Saturday, 7 February. That evening, seemingly unconscious of the irony, O'Connor attended a performance of The Game of Speculation at the Lyceum Theatre. His repeated interruptions produced loud cries of "order" and "turn him out". A constable who intervened was struck in the face, whereupon O'Connor was arrested, taken to Bow Street Station and charged with assault. ${ }^{27}$ On the following Monday morning, he was sentenced to seven days in the Clerkenwell House of Correction, the magistrate observing that O'Connor seemed perfectly sane. G. W. M. Reynolds replied that although he was "perfectly calm and composed at times, he was decidedly mad when

\footnotetext{
${ }^{20}$ Ibid.

${ }^{23}$ The Times, 13 April 1853; People's Paper, 16 April 1853.

24 Morning Chronicle, 3 Feb. 1852.

${ }^{25}$ The Times, 13 April 1853; People's Paper, 16 April 1853.

26 Ibid.

${ }^{27}$ Morning Chronicle, 9 Feb. 1852.
}

21 Julius West, A history of the Chartist movement, London, Constable, 1920, p. 266.

22 Jacob Bell (1810-59), a chemist in Oxford Street, London and editor of the Pharmaceutical Journal, was first returned for St Alban's in December 1850 but, on 3 May 1852, the borough was disfranchised-for bribery and corruption-by act of Parliament. Bell was unknown to O'Connor before 1851 . 
any trouble occurred to him". ${ }^{28}$ O'Connor was placed in the infirmary, as both the governor and physician considered him insane. Jacob Bell claimed that as a result of this experience he "lost all self respect ... He was certainly much worse after coming out than on going in". ${ }^{29}$ Some two months later, a Notting Hill newsagent named Dunford petitioned the Hammersmith magistrates to restrain O'Connor, who, on a number of recent occasions, had "conducted himself in a most extraordinary manner" in the complainant's shop. The magistrate observed that he was powerless to act, although “it was generally understood that Mr O'Connor was insane". The magistrate was assured that steps were being taken to have O'Connor committed to an asylum, there being no longer any doubt as to the state of his mind..$^{30}$

O'Connor fled briefly to the United States, where he remained for a mere five weeks. On his return to London, events assumed an inevitability of their own. On 1 June, he visited in turn several of the law courts at Westminster Hall, gathering a tatterdemalion following, pied-piper fashion, as he went. This assemblage and his own interjections and observations combined to reduce the legal proceedings to farce. $^{31}$

At the same time, his behaviour in the House of Commons became more pronounced. On 8 June, Sir Benjamin Hall complained that he had been struck in the side by O'Connor. The latter was named by the Speaker and subsequently apologized. ${ }^{32}$ The Times was unequivocal: O'Connor was “a maniac . . . a dangerous madman"; society must take steps to protect itself. ${ }^{33}$ On the very day this editorial appeared, the Attorney-General was interrupted by O'Connor's “disorderly and offensive conduct". Mr Beckett Denison remonstrated with him, the official Parliamentary report continued, whereupon O'Connor "thrust his half-closed hand" into Denison's face. ${ }^{34}$ A significantly different perspective was provided by the Parliamentary Correspondent of The Times: O'Connor "conveyed his fingers to the face of the hon. Member as if he were about to pull his nose". ${ }^{35}$ Denison complained and O'Connor was called before the House. Jacob Bell moved for a medical certificate, but an amendment committing O'Connor to the custody of the Serjeantat-Arms was carried instead. ${ }^{36}$

Bell believed that O'Connor was not responsible for his actions and immediately called in two distinguished doctors, the physician, Dr Alexander Tweedie and the surgeon, William Lawrence. After lengthy interviews, both certified him insane, Tweedie suggesting that unless restrained, O'Connor might become dangerous to himself and others. Lawrence concluded that O'Connor was incapable of managing his affairs and that he was not fit to be at liberty. ${ }^{37}$ Harriet Bernard Browne

${ }^{28}$ Ibid., 10 Feb. 1852.

29 People's Paper, 16 April 1853.

30 The Times, 15 April 1852.

${ }^{31}$ Ibid., 2 June 1852.

${ }^{32}$ Hansard, HC debs, 3s, cxxii, cols. 273-4.

${ }^{33}$ The Times, 9 June 1852.

${ }^{34}$ Hansard, HC debs, 3s, cxxii, col. 367.

${ }^{35}$ The Times, 10 June 1852.

${ }^{36}$ Hansard, HC debs, 3s, cxxii, cols. 367-73.

${ }^{37}$ The Times, 11 June 1852. 


\section{O'Connorite Bedlam}

O'Connor immediately petitioned the House of Commons that her brother be discharged from custody, so that he could be placed in confinement under proper medical treatment. A Select Committee was appointed to examine the facts of the petition. ${ }^{38}$

On 15 June, Dr John Conolly, ${ }^{39}$ consulting physician to the Middlesex County Pauper Lunatic Asylum at Hanwell, examined O'Connor. On the following day, Dr Thomas Harrington Tuke, Conolly's son-in-law and owner of a private lunatic asylum, Manor House, Chiswick, was sent for by the Select Committee. He found O'Connor in a voluble and excited state, laughing and crying, roguish and deferential, lively and timid by turn. The internee was conscious of his present situation and the reasons for it, but the events of the preceding three months were a blank in his memory, occasioned, no doubt, by his daily consumption of 15 glasses of brandy during this period. The psychiatrist concluded that O'Connor was suffering from general paralysis of the insane and prognosticated a fatal termination within a few years. ${ }^{40}$

Tuke volunteered to take charge of the lunatic. He and Harriet O'Connor gave a written guarantee that the latter's brother would not be removed from the asylum without the express permission of the Commons. The Select Committee then recommended to the House that O'Connor be discharged from the custody of the Serjeant-at-Arms. In the late afternoon of 16 June, he was taken to Chiswick, under police escort, and lodged in Manor House Asylum. ${ }^{41}$

Tuke was convinced, as were Conolly and Tweedie, the consultant alienists associated with the case, that O'Connor was suffering from general paralysis of the insane (GPI). The symptoms described by them and by several of the patient's friends and acquaintances, notably memory loss, great emotionalism, delusion, and exaltation, are characteristic of the first stage of the disease. General paresis or general paralysis of the insane, also known as dementia paralytica and Bayle's disease, is a physical and mental disease due to syphilis of the nervous system, which usually begins eight to twenty years after infection. O'Connor never married but, according to his biographers, had a succession of affairs and fathered several illegitimate children, including Edward O'Connor Terry, the celebrated music hall artist and theatre owner. ${ }^{42}$ The begetting of bastards seems to have been something of an O'Connor family forte.

The mental symptoms of general paresis may appear in various forms, the most common being simple dementia, a deterioration of intellect, affect, and social

${ }^{38}$ Hansard, HC debs, 3s, cxxii, col. 611.

${ }^{39}$ For Conolly, see Andrew Scull, 'A Victorian alienist: John Conolly, FRCP, DCL (1794-1866)', in W. F. Bynum, R. Porter and M. Shepherd (eds.), The anatomy of madness: essays in the history of psychiatry, vol. 1, People and ideas, London, Tavistock, 1985, pp. 103-50; idem, 'A brilliant career? John Conolly and Victorian psychiatry', in Victorian Stud., 1984, 27: 203-235.

${ }^{40}$ Lancet, 1855 , ii: $302-3$.

41 The Times, 17 June 1852 . Two features of the case are worthy of comment. Firstly, the tardiness with which action was taken on O'Connor's obvious insanity is probably explained by the fact that he was a sitting Member of the House of Commons and that his case was unprecedented. Secondly, the extraordinary lack of charity and sympathy displayed by Tory politicians and the conservative press generally was undoubtedly a legacy of the personal and political hostility that his radicalism and his renunciation of the establishment had aroused.

${ }^{42}$ Read and Glasgow, op. cit., note 11 above, p. 142. 
behaviour. The neurological symptoms and signs that may appear are epileptic attacks; Argyll Robertson pupil; tremor, frequently affecting the muscles of the hands and fingers, so that handwriting degenerates greatly; impaired oculomotor activity; optic atrophy; impaired motor function, including ataxia, poor co-ordination, unsteady gait, weakness; slurred speech; hyperactive reflexes; loss of bladder and bowel control.

General paresis was first described in 1798 and again, by Bayle, in 1822. The term "general paralysis of the insane" was first used in 1824 and the relationship of the disorder to syphilis was first suggested in 1857, two years after Feargus O'Connor's death. The identification of the spirochete as the cause, rather than merely a predisposing factor, was made possible in 1911, when Hideyo Noguchi demonstrated the presence of organisms in the brains of paretic subjects. In the pre-penicillin era, the whole course of the disease generally took only two to three years, before terminating fatally. Occasionally, however, remissions took place, which prolonged life to ten years or more. ${ }^{43}$ In O'Connor's case, diet was carefully regulated and he was given a small quantity of wine daily. Sedatives had a deleterious effect and were quickly dispensed with. For some time, his sole medical treatment consisted of bitter tonics, mineral acids, and occasional aperients. ${ }^{44} \mathrm{He}$ died, agonizingly, at the end of August 1855, just over three years after his commitment to Dr Tuke's asylum.

A fortnight after the Manor House gates had closed behind her brother, Harriet O'Connor appealed to Chartists in general on his behalf. Feargus, she stated, "needs quiet to quell the excitement under which he is continually labouring. This can only be achieved by continuing him under proper medical care-it is for this purpose your aid is claimed". ${ }^{45}$ Harriet's request was endorsed editorially by Ernest Jones in the People's Paper and by Julian Harney in the Star of Freedom. Jones wrote: "Feargus O'Connor, the champion of popular liberty for twenty years and upwards, is ill, helpless and powerless and needs the aid of the people for whose sake he became so". ${ }^{46}$ Harriet requested that a portion of the money subscribed for her brother be released for her own upkeep. Prior to his illness, Feargus had resided with his sister, who depended completely on him for financial support. "Deprived of that stay", Harney noted, "her position is now a most unhappy one-to be imagined, perhaps, but not to be described". Nonetheless, Dr Tuke refused to assign any of O'Connor's property entrusted to him to any outside agency, familial or otherwise. ${ }^{47}$

On 18 February 1853, Harriet O'Connor appealed to the Hammersmith police court to have her brother restored to her as she wished to transfer him to a different

\footnotetext{
${ }^{43}$ Robert Jean Campbell, Psychiatric dictionary, 5th ed., New York and Oxford, Oxford University Press, 1981, p. 447; C. W. H. Havard (ed.), Black's medical dictionary, 35th ed., London, A. \& C. Black, 1984, pp. 394-5.

44 Lancet, 1855, ii: $302-3$.

45 People's Paper, 3 July 1852.

46 Ibid., 7 Aug. 1852.

47 Star of Freedom, 9 Oct. 1852. Impecuniosity seems to have been the hallmark of Harriet O'Connor's life. Some 20 years earlier, she had appealed, unsuccessfully, to her father for financial assistance. A post-mortem visit to his humble cottage at Ballincollig, County Cork, proved more fruitful. In the course of a scuffle she managed to wrestle from his quondam mistress, inter alia, a blunderbuss, a turkey-cock, and a blanket. Daunt, op. cit., note 6 above, p. 252.
} 


\section{O'Connorite Bedlam}

asylum. Mr Westbrook, her solicitor, claimed that she had made several unsuccessful attempts to have her brother released into her keeping. Dr Tuke was invariably absent from the asylum on these occasions and refused to furnish an explanation. When O'Connor entered the institution, Westbrook continued, some $£ 1,700$ belonging to him had been lodged jointly in the names of Tuke and Jacob Bell. Westbrook concluded that the alienist had been recompensed for his ministrations and should have no objection to restoring O'Connor to his sister. The magistrate said he had no jurisdiction in the matter and advised them to apply at once to the Commissioners in Lunacy. ${ }^{48}$

The allegations were publicly denied by Tuke and by O'Connor's nephew, Roger. The former rejected the several implications in Westbrook's submission: O'Connor was not being maltreated nor was he under any form of constraint; his solicitor, family and friends had ready access to him, the patient was perfectly content and happy. "Everything was with him couleur de rose", as Tuke expressed it on another occasion, "and it would have been impossible to have made him feel miserable, even had the experiment been tried". The amount of money belonging to O'Connor had been greatly exaggerated, he concluded. ${ }^{49}$ Roger O'Connor came out strongly in support of the asylum-keeper who, he said, had treated his uncle with the greatest possible kindness and attention. Tuke had assured him that Harriet had never been denied access to her brother and, in reply to her single application to have Feargus transferred to another asylum, had merely pointed out that any enforced change would have a deleterious effect on his condition, an observation subsequently corroborated by independent medical testimony. Tweedie and Lawrence, the doctors who had originally certified O'Connor, re-examined him on 22 February 1853 and submitted the following certificate to the House of Commons: "We find that $\mathrm{Mr}$ O'Connor has all the comforts possible in his case and that his disease is worse. We think his removal from Dr Tuke's would be most inexpedient". Another doctor, who was independent of all parties involved in the case, reported that he left the asylum convinced that the patient could not receive better treatment anywhere else. ${ }^{50}$

On 12 March 1853, Ernest Jones reported at length in the People's Paper on a recent visit he had paid to Manor House. O'Connor was not under any constraint, he wrote. On the contrary, he was treated well and seemed perfectly content. The patient dined with the Tukes and spent his day playing billiards, arranging books, and going for walks in the grounds. "He expressed in plain and explicit terms that he was perfectly comfortable and had no desire for leaving". According to Jones, O'Connor's condition was hopeless:

He is but a wreck of his former self ... His mind is a perfect wreck and the extinction of his once mighty intellect may be seen in the mild dimness of his clouded eyes. There is no wildness or fierceness in their expression — but a manifest dying out of the light of mind. A gradual paralysis is stealing on his frame-shewing itself in a disinclination for exertion and a heaviness of motion.

48 The Times, 19 Feb. 1853.

49 Ibid., 22 Feb. 1853; Lancet, 1855, ii: 302-3.

50 The Times, 26 Feb. 1853; People's Paper, 16 April 1853. 
The remainder of the report is concerned with the relations between $\mathbf{O}^{\prime}$ Connor and his sister. Feargus manifested the greatest antipathy towards her. "He evinces the most lively dread of being near her... When her name was mentioned or the bare idea hinted at - he grew violently excited and cried: 'Keep her away! Don't let her come near me! I won't go to her! Let me stay here!'” Harriet was determined, Jones continued, to have her brother removed from Dr Tuke's care and to have him placed in another asylum, irrespective of its character. Her motivation was not her brother's well-being but a determination to get control of his estate. Jones believed that such interference would kill him. "The mischief that Miss O'Connor has caused is incalculable", he concluded. ${ }^{51}$

In mid-March 1853, Roger O'Connor applied for a Commission de lunatico inquirendo in order to have his uncle placed under the protection of the Lord Chancellor, thereby safeguarding him and his property from Harriet's designs. The inquiry opened before Francis Barlow and a jury of freeholders of the county of Middlesex at the Roebuck Tavern, Chiswick, on Tuesday 12 April. Sergeant Shee, who appeared on O'Connor's behalf, and the patient's friends, Ernest Jones and Dougal McGowan, related the history and circumstances of his malady. The inquiry was necessary, Shee informed the jury, to safeguard the subject's property. This amounted to a mere $£ 1,300$ or $£ 1,400$ but $O^{\prime}$ Connor's life expectancy was such that it would probably be sufficient to maintain him for the remainder of his days. "But", he stressed, "if the protection of the Court of Chancery were not thrown round him, there could be very little doubt he would end his days in a workhouse". Jones concluded his lengthy testimony by expressing his conviction that O'Connor was "of unsound mind". McGowan had visited the patient on the previous Sunday and found him to be "in a perfectly idiotic state". Jacob Bell was convinced that O'Connor's condition was deteriorating. Drs Tweedie and Conolly pronounced him incurably insane. At this point, the commissioner, jury members, counsel and witnesses, some thirty individuals in all, adjourned to Manor House to "interview" the inmate. "The shrill voice of the unhappy man was heard echoing through the passages in joyous accents", The Times reported. O'Connor, recognizing Jones and Bell, welcomed them effusively. Subsequently, he gave a highly excited and voluble recitation of the doggerel verse, 'The Lion of Freedom'. He was unable to make a single coherent reply to the several questions put to him. Tuke held out not the slightest hope for his recovery. The jury, without retiring, found that O'Connor had been insane, without lucid intervals since $10 \mathrm{June} 1852$ and that he was incapable of managing his affairs. ${ }^{52}$

O'Connor's person and estate, which amounted to $£ 1,1677 \mathrm{~s} .0 \mathrm{~d}$. at the end of June 1853, were now afforded the formal protection of the Lord Chancellor. Subsequently, Dougal McGowan was appointed as the Committee of the Estate, responsible to the Lord Chancellor, to look after O'Connor's affairs and to safeguard the heirs' interests. Harriet O'Connor objected, unsuccessfully, to McGowan's appointment on the grounds that he had purchased her brother's newspaper, the Northern Star, for $£ 100$, a figure she considered ridiculously inadequate. The fact that McGowan and

51 People's Paper, 12 and 19 March 1853.

52 The Times, 13 April 1853; People's Paper, 16 April 1853. 


\section{O'Connorite Bedlam}

Fleming, the paper's editor, were forced to dispose of it for $£ 40$ after running it at a loss for five months failed to convince her of its intrinsic worthlessness. ${ }^{53}$

By this time, mid-1853, O'Connor's condition was hopeless. His speech had become unintelligible, his vision impaired, and his facial expression decidedly altered; his gait was unsteady, his balance unsure, and he had a marked tendency to fall forward. His childhood friend recorded on 19 November that O'Connor was believed to be near death. In June 1854, he had the first of a series of severe epileptic seizures which were to leave him totally helpless. Cotyledon umbilicus ${ }^{54}$ was now prescribed for him. In September, a second attack was followed by loss of sphincter control, and the patient's daily ration of wine was subsequently increased to three glasses. In January 1855 , he had a particularly severe fit, as a result of which he lost both the ability to speak, and to walk unaided. He suffered excessively from the cold. In March, his circulation slowed down remarkably and sores developed on his thighs and back. Thereafter, he slept on a waterbed and the sores gradually disappeared. By June, he had become perfectly helpless, lifting his hands only with the greatest difficulty. His bowels were sluggish and his urine had to be drawn off occasionally by a catheter. He had frequent convulsive attacks, often brought on by attempts to lift him out of bed. Touching his hand produced reflex motions that lasted for some time. It became necessary to feed him at short intervals, both night and day. "Under this treatment", Tuke concluded, "he did not lose flesh; he seemed cheerful and pleased at the presence of visitors, though unable to recognise former friends". 55

In August 1855, on the petition of Harriet O'Connor, a new Committee of the Estate was appointed by the Court of Chancery. By this authority and in opposition to his nephew's expressed wish, Feargus O'Connor was removed from Manor House Asylum - seven men being required to lift him into the carriage - to his sister's house in Notting Hill, where he died ten days later, on 30 August. ${ }^{56}$ "The attendants left the room", according to one report, "unable to bear the sight of his torments or to listen to his agonising groans". 57

On the application of Roger O'Connor, an inquiry was opened before Thomas Wakley, one of the Middlesex coroners, during the course of which Harriet asserted that Tuke and her nephew had colluded over the years to deprive her of her brother. "Dr Tuke frequently gave him [Roger] half a sovereign for his assistance", she observed. "Dr Tuke was not so liberal as to give him money for nothing, for she had heard that he only gave the sexton $6 \mathrm{~d}$ when he was married!'. Dr Charles Clark, who attended O'Connor at his sister's residence, attributed his death "to inflammation of the brain of old standing". The jury, on the coroner's instructions, returned a verdict of death "by natural disease" 58 Wearing his other hat as owner and editor of the

53 The Times, 25 and 29 June 1853.

54 Now called Umbilicus rupestris; commonly known as kidney wort, penny wort, navel wort, wall-penny royal: a member of the Crassulaceae family, it was used to treat epilepsy. For a scathing comment on its efficacy, see Lancet, 1852, ii: 239.

${ }_{55}$ Lancet, 1855, ii: 302-3.

56 Ibid., p. 301.

${ }^{57}$ Daunt, op. cit., note 6 above, p. 127.

58 The Times, 4 and 7 Sept. 1855. For a post-mortem examination of O'Connor made by Clark and Edward Smith, MD, LSA, see the Appendix. 


\section{Laurence M. Geary}

Lancet, Wakley opined that O'Connor's death was hastened by his removal from Dr Tuke's care and the change of medical treatment, an interference he characterized as injudicious, if well-meant. Wakley was at pains to exonerate Tuke and those who attended O'Connor in his final days. "The kind intention of Mr O'Connor's sister cannot be doubted for a moment", he concluded. "She was greatly attached to her brother and attended him in his last moments with the most anxious care and solicitude". 59

O'Connor was interred at Kensal Green Cemetery on Monday 10 September 1855 , the funeral expenses being defrayed by public subscription. The Times estimated that between 15,000 and 20,000 people attended the funeral, while a similar number lined the route from Notting Hill to Kensal Green. Banners proclaiming "He lived and died for us" were much in evidence. In his graveside panegyric, William Jones, a Liverpool working-man, asserted that O'Connor was a man more sinned against than sinning. It was not entirely inappropriate, perhaps, that during the proceedings several pickpockets were apprehended as they went about their unlawful business. ${ }^{60}$

The immediate public reaction to the assault on Queen Victoria by Feargus O'Connor's grand-nephew, Arthur, in the late afternoon of 29 February 1872 was a confusion of shock, horror, and outrage. Raging passion gave way to derision, however, once the circumstances of the attack became known. "Burlesque" was the adjective favoured by The Times. ${ }^{61}$ The Observer dismissed O'Connor's pistol as "a rusty piece of old iron" and the assault itself as the deranged act of an insane individual. ${ }^{62}$ The folly and depravity of the attack convinced Gladstone that the Queen's assailant was not wholly master of his senses, while the Home Secretary concluded that he was "weak-minded and perverse, the easy victim of delusions". 63

The Queen drew little comfort from these public and private expressions of her assailant's obvious mental aberration. She had been shocked and frightened by her experience, as she privately admitted. Palace security had been breached with ridiculous ease and Victoria was apprehensive about further attacks. "These Fenians are horrid reckless people", she confided in her eldest daughter, the Crown Princess of Prussia. ${ }^{64}$

The Queen was convinced of O'Connor's sanity and was opposed to having his assault upon her dismissed as the dim-witted action of an obviously deranged individual. She was determined that the full severity of the law be brought to bear in order to deter possible future assailants and would-be regicides. Gladstone was

${ }^{59}$ Lancet, 1855 , ii: $302-3$.

${ }^{60}$ The Times, 11 Sept. 1855.

${ }^{61}$ Ibid., 1 March 1872.

62 Observer, 3 March 1872.

${ }^{63}$ Gladstone to Queen Victoria, 29 Feb.-1 March 1872, in Philip Guedalla, The Queen and Mr Gladstone, 2 vols., London, Hodder and Stoughton, 1933, vol. 1, pp. 338-9; Bruce to the Queen, 1 March 1872, in Buckle, op. cit., note 2 above, p. 200.

${ }^{64}$ The Queen to her daughter, Victoria, 4 March 1872, in Roger Fulford (ed.), Darling child: private correspondence of Queen Victoria and the Crown Princess of Prussia, 1871-1878, London, Evans Bros., 1976, pp. 33-4. See also Nigel Walker, Crime and insanity in England, vol. 1: The historical perspective, Edinburgh University Press, 1968, pp. 186-90. 


\section{O'Connorite Bedlam}

bluntly told to amend the existing legislation if it proved inadequate. Moreover, she added, O'Connor should be exiled on the expiration of his sentence. ${ }^{65}$

Arthur O'Connor was the eldest of eight children of Roger O'Connor-he who had evinced so much concern for his uncle Feargus's welfare and for Dr Tuke's reputation almost 20 years earlier-and his wife Catherine. Arthur was educated at St Dunstan's Church School, Fleet Street, and afterwards worked as a clerk, first in a law stationer's firm and later in the wholesale warehouse of Lovett and Francks, oil and colour manufacturers, where his wages were 12 shillings a week. O'Connor was a somewhat introverted youth, who listed reading, writing, and drawing as his pastimes, and numbered Dickens, Thackeray, Dumas, Victor Hugo, Bulwer Lytton, and Samuel Lover among his favourite authors. He had been dogged by ill health for several years. He was dyspeptic, subject to bouts of dizziness and, as a result of osseous disease, had to have one of his big toes amputated. Some years earlier, O'Connor had been knocked down by a hansom cab and had received a severe scalp wound as a result of which he became noticeably irritable and short-tempered. Prior to his attack on the Queen, he complained of headache, sleeplessness, and fatigue. ${ }^{66}$

O'Connor informed Dr Bond, one of the physicians who examined him in Newgate, that he sympathized with Irish republican ideals and was moved to action by the plight of the Fenian prisoners in English gaols. After some consideration, he rejected regicide as the means of securing their release, opting, instead, to confront the Queen at gunpoint in the aisle of St Paul's Cathedral on the thanksgiving day and to barter her safety in return for an unconditional pardon for the imprisoned Fenians. ${ }^{67}$

O'Connor's was the penultimate of seven separate attacks on the Queen, all but one of which involved the use of pistols. The first occurred more than 30 years earlier when, on 10 June 1840, the 18-year-old Edward Oxford fired two shots at Queen Victoria and Prince Albert as they drove in their carriage near Hyde Park corner. Oxford was charged with high treason but was acquitted on the ground of insanity and committed indefinitely to the criminal lunatic asylum in Southwark. The jury believed him to be of unsound mind at the time of the attack. In addition, they were unable to decide whether or not the pistols were loaded with ball. The Queen's next assailant, John Francis, was found guilty of treason but the obligatory death sentence was commuted to transportation for life, after the Home Secretary had intervened, on the ground that the pistol was loaded with powder but not with ball. The Treason Act proved singularly inappropriate in each of these cases. To overcome the difficulties presented to the judiciary and executive alike, an Act was passed in 1842 which distinguished between attempted regicide and high misdemeanour, which merely involved annoying or alarming the sovereign. The punishment was to be seven years' transportation, or up to three years' imprisonment, with hard labour and flogging being imposed at the judge's discretion. ${ }^{68}$

\footnotetext{
${ }^{65}$ Journal entry, 1 March 1872, in Buckle, op. cit., note 2 above, p. 199, and Queen Victoria to Gladstone, 1 March 1872, in Guedalla, op. cit., note 63 above, p. 339.

${ }^{66}$ Annual Register, 1887, pp. 209-13; The Times, 4 March and 12 April 1872; Lancet, 1872, i: 341-2, 515, 535-6, 546-7, 571-2.

67 The Times, 12 April 1872; Lancet, 1872, i: 341-2, 515, 571-2.

${ }^{68}$ Walker, op. cit., note 64 above, pp. 186-90. For Edward Oxford, see F. B. Smith, 'Lights and shadows in the life of John Freeman', in Victorian Stud., 1987, 30: 459-73.
} 


\section{Laurence M. Geary}

O'Connor pleaded guilty before Baron Cleasby at the Central Criminal Court to the charge of high misdemeanour in presenting a pistol at the Queen with intent to alarm her, but, before sentence could be pronounced, a preliminary issue was raised by Mr Hume Williams, counsel for the defence, as to the prisoner's capacity to plead when arraigned and he requested that a jury be empanelled to decide the issue. The defence argued that O'Connor was insane at the time the offence was committed. Accordingly, the proper plea was one of not guilty on the ground of insanity. The judge ruled, however, that evidence of previous insanity was irrelevant; what mattered was the accused's current state of mind. Dr Thomas Harrington Tuke was the first medical witness to testify. He had examined the prisoner in Newgate, at the request of the boy's father, Roger O'Connor, and had subsequently called in his colleagues, Dr Alexander Tweedie, Dr Henry Maudsley, Dr James Thompson Sabben, and Mr Henry Smith. They concurred that O'Connor was a weak-minded and potentially dangerous individual who should not be allowed to remain at large. In Tuke's opinion, the accused was shrewd and intelligent, capable of conversing clearly and rationally on many subjects; physically, he was weak and effeminate, with a smaller than average sized head and a highly arched palate; the pupils of the eyes were widely dilated and the eyes themselves had the glistening appearance which, according to Tuke, so frequently accompanies disease. Several factors-delicacy of mind and body, hereditary insanity, scrofula, and a blow to the head-had combined to produce a paroxysm or exacerbation of insanity in the accused about the time he devised his scheme to free the imprisoned Fenians. Tuke defined O'Connor's malady as a very dangerous form of "reasoning insanity" or folie raisonnée. The victim might be sane enough, he explained, and might reason clearly and properly, but it would always be within a circle. Tuke opined that O'Connor's condition could deteriorate at any time and he advocated his immediate committal to a lunatic asylum. ${ }^{69}$

J. Rowland Gibson, surgeon to Newgate Prison, sought to distinguish between an unreasonable and an insane action. O'Connor may have been impelled by some absurd delusion, he argued, but the act of attacking the Queen did not of itself imply insanity. Gibson concluded that the accused was not only fully aware of the nature of his action, he was also perfectly sane. ${ }^{70}$

At this stage, the foreman of the jury interposed and announced that they were quite convinced of O'Connor's sanity throughout. Baron Cleasby stated that he was entirely of the same opinion. In passing sentence, he took into account such mitigating factors as O'Connor's youth and what he termed the "absurdity" of the attempt itself. The judge believed that the accused had acted under some enthusiasm which blinded him to the real nature of his action. O'Connor was sentenced to 12 months' imprisonment with hard labour and 20 strokes of the birch. ${ }^{71}$

The Queen was furious. "Only one flogging with merely a year's imprisonment and hard labour!" she exclaimed. ${ }^{72}$ Gladstone expressed his astonishment at the leniency of the sentence and at the absurdity of the judge's charge. He was convinced that a

${ }^{69}$ The Times, 12 April 1872; Annual Register, 1887, pp. 209-13.

70 Ibid.

71 Ibid.

72 The Queen to her daughter, Victoria, 13 April 1872, in Fulford (ed.), op. cit., note 64 above, p. 38. 


\section{O'Connorite Bedlam}

good deal of the mischief in the case resulted from "the gratuitous intervention of $\mathrm{Dr}$ Tuke", ${ }^{73}$ an observation shared by many of the latter's professional peers who believed that Tuke's championing of O'Connor's case was self-aggrandizingly rather than altruistically motivated. The Lancet argued that it would have been better to have let the law take its proper course and to have let the judge and jury punish the accused as they thought fit. "One or two or even three years committal to Newgate would be a much milder sentence than life long incarceration at Broadmoor as a criminal lunatic", the editorial writer concluded. ${ }^{74}$ Edgar Sheppard MD, Professor of Psychological Medicine at King's College and Medical Superintendent of the male department of Colney Hatch asylum, categorized the insanity plea put forward by his colleague, Dr Tuke, as flimsy, and was dismissive of the defence argument in general. $\mathrm{He}$ condemned as monstrous the assertion by O'Connor's counsel and psychological apologists that the accused did not understand the nature of his plea. Sheppard, who had examined O'Connor on two separate occasions prior to his trial, concluded: "I venture to say that if he is mad I never saw a madman yet; and I am supposed to see some hundreds daily", ${ }^{75}$ an observation that merely confirmed the previously published opinions of Drs Bond and Sutherland, who had examined O'Connor when he was first taken into custody. ${ }^{76}$

In Sheppard's opinion, O'Connor was vain and self-opinionated, irresponsible and overly excitable; his inability to distinguish between crime and heroism and his leaning towards Fenianism were considered to be the source of all his troubles. Sheppard was in no doubt that the fount of O'Connor's political enthusiasm was his unfortunate addiction to sensational literature:

As one would hardly expect a healthy body associated with a dietetic regimen of trifle and tipsy-cake, one could not think of a healthy mental development from a literature of highly wrought sensational fiction. The document produced in court as written by O'Connor was a wild rhapsodico- hysterical shriek of Victor Hugoism. It bore no more internal evidence of insanity than some of Hugo's screaming nonsense written to his countrymen during the German occupation of France. I would label "poison" upon the works of this author and Dumas, and place them out of the reach of British youth.

The professor believed that O'Connor was possessed of some very fine qualitiesintelligence, honour, integrity, truthfulness, a fine moral perception - but that he had been misdirected. Sheppard was convinced that with careful management, good diet, fresh air and wholesome teaching, O'Connor could be guided onto the proper path:

His apologists have mistaken honest but foolish political convictions for "delusions" and an act of mock-heroism for an "insane impulse". He has neither delusions, nor illusions, nor hallucinations. He has been improperly handled and has made a young fool of himself. If the future will handle him-or rather, if he will handle the

\footnotetext{
${ }^{73}$ Guedalla, op. cit., note 63 above, pp. $344-8$.

74 Lancet, 1872 , i: $546-7$.

75 Ibid., pp. 535-6.

76 Ibid., pp. 341-2, 515.
} 


\section{Laurence M. Geary}

future-differently, he should become a wise and sensible (though he will never be a strong) man. ${ }^{77}$

In a scathing personal attack, the Lancet accused Tuke of widening the existing breach between the professions of law and medicine regarding criminal insanity. According to the editorial writer, he had compounded his initial indiscretion of suggesting the plea of insanity by his evidential use of exclusively professional terminology and by drawing shadowy psychological distinctions in a case that untutored common sense was perfectly competent to deal with. As a result, Tuke, and alienists in general, had been subjected to a good deal of ridicule in the popular press. More significantly, the Lancet concluded, the question of criminal insanity had been frozen and was further than ever from resolution. In addition, the gulf between law and medicine had been widened at a time when the legal profession were displaying both jealousy and hostility towards their medical confrères. ${ }^{78}$ Tuke was stung into making a lengthy reply. He adhered steadfastly to his opinion that at the time of the attack on the Queen, O'Connor was dangerously insane and, as such, the plea should have been one of "not guilty" on the ground of insanity. He was fully aware, as was Roger O'Connor, that indefinite custody in an asylum for the criminally insane axiomatically followed a successful acquittal on a plea of insanity, a penalty far in excess of any that could be imposed under the Act of 1842 . He was convinced that the defence was correct in attempting to question the accused's capacity to understand the nature and result of his plea. Tuke rejected the accusation that his evidence had in any way deleteriously affected medico-legal relations. He concluded that O'Connor was presently in his normal state but, he warned, his paroxysms of dangerous lunacy could recur at any time. ${ }^{79}$

On the expiration of his sentence in 1873, O'Connor was bundled off to the Australian colonies where his condition of "insane hypochondriasis", to use Tuke's phrase, continued. He suffered occasional bouts of absolute mania. In one of several letters to Queen Victoria he suggested that he be appointed Poet Laureate in succession to Tennyson. O'Connor's antipodean stay proved to be a sojourn rather than an exile and on 5 May 1875 he was apprehended by detectives outside Buckingham Palace. ${ }^{80}$ Tuke and Tweedie, who examined him that evening on the instructions of the Secretary of State, concluded that he was "excited and insane". O'Connor provided a written account of his condition:

"Physical Symptoms. Back like ice; want of ability to swallow food. Sinking in Stomach. In cold weather one moment - deadly cold, the next burning hot - pains in

\footnotetext{
77 Ibid., pp. 535-6.

78 Ibid., pp. 546-7. For a discussion on the insanity defence see Roger Smith, Trial by medicine: insanity and responsibility in Victorian trials, Edinburgh University Press, 1981; idem, 'The boundary between insanity and criminal responsibility in nineteenth century England', in Andrew Scull (ed.), Madhouses, mad-doctors, and madmen: the social history of psychiatry in the Victorian era, London, Athlone Press, 1981, pp. 363-77; idem, 'Defining murder and madness: an introduction to medicolegal belief in the case of Mary Ann Brough, 1854', in R. A. Jones and H. Kuklick (eds.), Knowledge and society: studies in the sociology of culture past and present, vol. 4, Greenwich, Conn., JAI Press, 1983, pp. 173-225.

${ }^{79}$ Lancet, 1872, i: 571-2.

$80 \mathrm{Br}$. Med. J., 1875, i: 658.
} 


\section{O'Connorite Bedlam}

the head-completely stupified by cold weather-Mental-want of rest-thought continually revolving upon religion. Visions at night of angels hurling men down precipices to die for ever because they had not given up all they loved and go and sell Bibles to the unconverted. Sense that unless I gave up the drama, witty and convivial Society, novel writing, and the world completely I should be everlastingly damned. In a word, one unceasing mania concerning Jesus Christ-the intellect warring with extreme views yet unable to crush the ever revolving mania. Sense of utter want of constitution and energy in comparison to what I ought to be.

"Naturally I am a poet loving the dramatic writers and poet of nature and at one time of my life, ere I become physically debilitated, quite unsusceptible to the present mania, which leaves me no rest day nor night. Of late my brain agony has terribly increased I awoke the other night raging to commit suicide; the idea occurred as a very delightful one, and just as I was about to spring from my bed to act upon it-it passed off and left me trembling all over and utterly horrified.

"Since then my feelings have risen to absolute madness continually and I know very well it is all physical desease, a dead liver or something of the kind. My home is very wretched, it is in fact a hell to me.

"Naturally I am devoured by energy, running in my walk, and in everything else, but when stupified by dyspepsia scarcely able to drag a foot" ${ }^{81}$

O'Connor was committed to Hanwell Asylum on the following day, 6 May 1875, where his mental disorder was classified as imbecility, caused by hereditary factors and masturbation. He was diagnosed as being both suicidal and homicidal. ${ }^{82}$

Thus exculpated, Tuke launched a searing attack on the tactics employed by some lawyers in order to secure a verdict, particularly the contemptuous dismissal of expert medical testimony in cases of insanity. "Hard labour and stripes and a short imprisonment as a felon are not likely to cure insanity", he observed pungently. Tuke recommended that the legal profession either educate themselves regarding insanity or else accept the opinions of those "who make medical and other scientific investigation the pleasure and business of their lives". ${ }^{83}$ Prosecuting counsel in the O'Connor case, Sir John Coleridge, the Attorney-General, had not ignored expert medical advice, he had merely listened to the wrong experts. Counsel had been briefed by Edgar Sheppard, who was convinced, as were several other medical witnesses, of O'Connor's sanity. Sheppard attempted to deflect criticism by arguing that the fundamental issue was not O'Connor's present insanity, which he conceded, but the state of his mind at the time of his trial three years earlier. Medical opinion had been divided and Tuke's "scientific evidence" had failed to alter his professional opinion or to convince the jury that O'Connor was other than perfectly sane. ${ }^{84}$ Sheppard's claims were rejected as specious and meretricious by Tuke, J. Crichton Browne MD, West Riding Asylum, Wakefield, and J. T. Sabben MD. All three argued that O'Connor had displayed no new symptoms of insanity and his present condition was the strongest indication of his madness in 1872 . Sabben was caustic:

${ }^{81}$ Ibid., pp. 672-3.

82 Greater London Record Office, records of Hanwell Asylum, Register of Admissions, HII/HLL/B5/9; Register of Admissions of Males, HII/HLL/B4/4.

${ }_{83} \mathrm{Br}$. Med. J., 1875, i: 672-3.

84 Ibid., p. 729. 
The diagnostic acumen which can discover indications of insanity in the recent conduct of this boy and could not discover insanity when instructed to examine him "by the Treasury" is, to say the least of it, somewhat curious. The reasoning faculty which can from two sets of similar facts arrive at two dissimilar conclusions certainly deserves the name of "expert". 85

On 16 November 1876, some 18 months after being committed to Hanwell Asylum, O'Connor was discharged, recovered. He was still a young man, not yet 23 years of age. However, in the absence of further documentation and biographical data, we can only assume that having ruffled regal, legal, and medical feathers, however unintentionally, he returned to the obscurity whence he came. ${ }^{86}$

\section{APPENDIX \\ Post-mortem Examination of the Body of the late Feargus \\ O'Connor, Esq., made Eighty-nine Hours after Death ${ }^{87}$}

The body was somewhat thin, but not emaciated, and there was an abundance of yellow and greenish fat in the subcutaeneous tissue of the abdomen and some other parts. There were no bed-sores or other marks of external injury, except a slight exfoliation of the skin on the buttocks and around the anus. There was no noticeable peculiarity in the expression of the countenance, but the cheeks were collapsed from decay and removal of the teeth. The head was not remarkably large, either absolutely, or in relation to the whole body. The following were the dimensions of the skull, taken externally:

The circumference around the base, over the ) organs of perception, destruction, and )

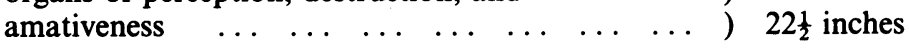

From the root of the nose to the occiput ... . ) $14 \frac{1}{4}$ "

From the tip of ear to ear across the frontal )

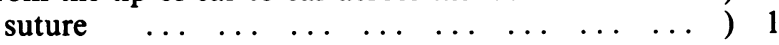

From the nose to the crown of the head ... . ) 10 "

The skull was of medium thickness; it was more or less translucent throughout, and exhibited but very slight depressions for the convolutions of the brain. The dura mater was separable from the bone with a most unusual degree of readiness, and there was injection of the minute vessels lying in the subarachnoid tissue at the base of the skull. The arachnoid was manifestly opaque in various places, but especially so on the superior aspect of the brain, and around the medulla oblongata. There were many membranous adhesions between the two layers of the arachnoid, along the whole extent of the falx major, the lateral aspect of the middle lobe, between the petrous portions of the temporal bones, at the base of the cerebellum, and more particularly at the anterior part, between the hemispheres at the anterior lobes. There were numerous small deposits of a whitish, non-cellular substance at the point of some of the adhesions. There were about six ounces of clear, straw-coloured fluid in the sac of the arachnoid and the upper part of the spinal canal, and there was also some of the same kind of fluid in the lateral ventricles. In the sub-arachnoid tissue covering the convolutions there was a large deposit of fluid over every part of the surface and at the base of the brain, containing many greenish exudation-cells. The vessels of the pia mater were much enlarged, and increased

85 Ibid., pp. 756-8.

${ }^{86}$ Greater London Record Office, records of Hanwell Asylum, Certificate of Discharge, HII/HLL/B9/10.

${ }^{87}$ Lancet, 1855 , ii: 303. 


\section{O'Connorite Bedlam}

in number, as were also the larger vessels of the external meninges, but they were not greatly congested. The substance of the brain was of an ash colour, and more consistent than is natural. There were numerous points of blood on every cut surface, but congestion was not the cause of the discoloration of the "white matter" just referred to. The grey matter of the corpora striata was softened, and consisted of the debris of brain-cells, and a few tubes, but without any exudation-corpuscles. In each of the anterior lobes, on either side of the fissure, there was a remarkable softening, of the size of a pigeon's egg. This extended back from the anterior extremity of the lobes, about an inch and a half, and was at the spot occupied by the organ of "comparison". This was also the position of the firm adhesions between the two anterior lobes. The softened matter contained very many exudation cells and beaded brain-tubes.

Thus there were evidences of most extensive, but distant, acute inflammation of the membranes of the brain, and also of the substance of the brain at the organ of comparison. The softening of the grey matter of the corpora striata, and the discoloration of the white matter of the brain, were probably due, not to inflammatory action, but to changes in the nutrition of the brain. The whole brain was contracted, so that it no longer filled the skull, but left a space, which was occupied by an increased quantity of the cerebro-spinal fluid. This was no doubt a chronic condition also resulting from mal-nutrition of the organ, as was also a similar state of contraction and hardness of the upper part of the spinal marrow. The whole spinal marrow was not examined.

There is but little to remark respecting the other internal organs, except that the kidneys, liver and heart presented abundant evidence of fatty degeneration. The heart was empty, and not enlarged, but its walls were very thin and flaccid, and the sarcolemma was in great part emptied of its muscular particles. There was much sub-pericardial fat, and the muscular structure was exceedingly pale. The kidneys were otherwise healthy. The gall-bladder contained three tolerably large gall stones; and one stone, as large as a small marble, was sacculated in the gall-duct within three-quarters of an inch of its commencement, but the duct was not altogether impervious. The lungs were fully distended and perfectly healthy, and the chest had an immense capacity, as shown by the following external admeasurement:

Circumference of the chest across the cartilage )

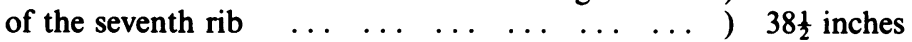

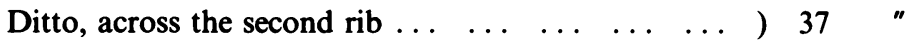

Antero-posterior diameter at the seventh rib... . . ) ) 9 "

Perpendicular length from top of sternum to )

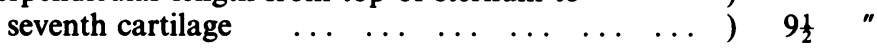

The spleen was not enlarged, but it was greatly softened.

Chas. Clark, MRCSL, LSA, \&c. Adelaide-terrace, Notting-hill.

Edward Smith, MD, LSA, Assistant-Physician to the Hospital for Consumption and Diseases of the Chest, Brompton. 